\author{
KereszTes-TAKÁcs Orsolya \\ keresztes-takacs.orsolya@ppk.elte.hu \\ doktorjelölt (ELTE Pszichológiai Doktori Iskola, \\ ELTE Interkulturális Pszichológiai és Pedagógiai Intézet)
}

\author{
ERŐS BARBARA
}

(ME Bölcsészettudományi Kar Antropológiai és Filozófiai Tudományok Intézete)

\title{
A roma gyermeket örökbefogadó szülők roma identitásról alkotott képe
}

\author{
Roma Identity Perception of non-roma Parents \\ adopting Roma Children
}

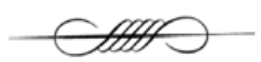

\begin{abstract}
The number of interethnic adoptions when non-Roma parents adopt Roma children is gradually growing in Hungary. The aim of the study is to introduce the perception of the Roma within a special segment of those Hungarian adoptive parents who adopt children with presumably Roma origins, but they do not identify themselves being Roma. The analysis discusses once the conceptualization and its appearance of the presumable Roma origin in nuclear or wider families that do not embody Roma identity. Also touches upon the contents and significations related to Roma identity and the importance of its transfer from adoptive parents to the adoptee. The study further highlights results of a research based on questionnaires focusing on Roma identity.
\end{abstract}

\section{KEYWORDS}

Roma identity, ethnic identity, adoptive families, interethnic families

DOI 10.14232/belv.2018.3.2 https://doi.org/10.14232/belv.2018.3.2

Cikkre való hivatkozás / How to cite this article: Keresztes-Takács Orsolya - Erős Barbara (2018): A roma gyermeket örökbefogadó emberek romákról alkotott képe. Belvedere Meridionale 30. évf. 3. sz. 33-54. pp. 
(Creative Commons) Nevezd meg! - Így add tovább! 4.0 (CC BY-SA 4.0)

(Creative Commons) Attribution-ShareAlike 4.0 International (CC BY-SA 4.0)

www.belvedere-meridionale.hu

\section{AZ ÖRÖKBEFOGADÁSI TRIÁD SZEREPLŐI ÉS A RENDSZER MŰKÖDÉSE - INTERETNIKUS NÉZŐPONTBÓL}

A pszichológiai értelemben örökbefogadási triádként emlegetett háromszög szereplőinek (PAVAO 2012), vagyis az örökbefogadott gyermeknek, az örökbefogadó szülőknek és a biológiai szülőknek is sajátos életútjuk van, melynek találkozását egy adott társadalmi kontextus övezi. Érdemes egy kicsit közelebbről megvizsgálni, hogy interetnikus szempontból milyen a szerepük az örökbefogadási rendszerben.

A romák strukturális szegénységének és kiszolgáltatottságának egyik tünete, hogy az örökbefogadási rendszerben folyamatosan nő a roma gyerekek száma. Köztudott a roma származású gyermekek felülreprezentáltsága a gyermekvédelmi szakellátásban (HAVAS - HERCZOG NEMÉNYI 2007), így az örökbefogadásra várakozó gyermekek között is feltételezhetően magasabb ez az arány, bár hivatalos adatainak erre vonatkozóan nincsenek (SzILVÁsı 2005). A hazai viszonyoknak köszönhetően a romák elleni diszkrimináció és elöítéletesség következtében az örökbefogadásra váró roma származású gyermekek nem roma társaikkal szemben hátrányos helyzetben vannak (NEMÉNYI - MEssing 2007; HAVAs - HerCzOG - NEMÉNYi 2007), hiszen az örökbefogadásra váró leendő szülők zöme, becsülten $80-90 \%$-a nem vállal cigány ${ }^{1}$ gyermeket (KERESZTES-TAKÁCS - NGUYEN 2017). Akik viszont örökbe fogadnak roma gyermeket, noha számuk már nő, környezetükben sokszor értetlenséggel és megvetéssel találkoznak és ennek kivédésére nem kaptak eddig megfelelő felkészítést a helyzet kezelésére.

Desk reserach kutatásaink során felmerült, hogy az örökbeadó szülő(k) valamilyen szempontból hátrányos helyzetüek: sok esetben anyagi gondok, de a rendezetlen családi, párkapcsolati háttér, tehát a nem megfelelő szociális háló is hozzájárul ahhoz, hogy a biológiai szülő(k) az örökbeadás alternatíváját válasszák. Jellemző a fiatalkori teherbeesés is az örökbeadók között. Ezen hátrányos helyzethez tartozó problémák összességben - a társadalmi berendezkedésből fakadóan - a romákat jobban sújtják. Persze nem lehet kijelenteni, hogy minden örökbeadóra jellemző lenne az alábbi élethelyzet, de az biztos, hogy prediktív faktornak számít és széles körben reprezentálják magukat az örökbeadók között az alacsony társadalmi osztályból kikerülő, anyagi és lehetetlen élethelyzetük miatt gyermekük örökbeadására kénytelen, sok esetben roma nők (KereszTEs-TAKÁCs - NGUYEn 2017).

Mindenekelőtt fontos annak tisztázása, hogy az örökbefogadási rendszerben ki számít romának (LADÁNYI - SZELÉNYI 2000), ugyanakkor, ahogyan általánosságban sem egyszerū ennek a kérdésnek

\footnotetext{
${ }^{1}$ Jelen tanulmányban a roma és a cigány kifejezéseket ekvivalensként, szinonimaként használjuk.
} 
a megválaszolása Magyarországon, úgy az örökbefogadás gyakorlati területén esetén sem az. Ahogy rengeteg irodalom hivatkozik rá (LADÁNYI - SzELÉNYI 2000; PÁLOS 2010) nincs egységes meghatározása annak, hogy ki számít cigánynak. Jelen tanulmányban nem is célunk ennek tárgyalása, hiszen kutatásunkban a szülők fogják meghatározni gyermekük etnikai hovatartozását, így ezt a minősítést fogadjuk el az etnikai hovatartozás beazonosítására. Örökbefogadás esetén sok esetben nem tisztázott a gyermek származása, hiszen nagyon sokszor az apák kiléte bizonytalan, illetve, ha a biológiai anya információi alapján nem egyértelmű, akkor nem tekinthetik az ügyintézők romának a gyermeket. Az is bizonyos, hogy örökbeadásnál a roma biológiai szülők nem szívesen vallják magukat romának (BOGÁR, 2011), hiszen tisztában vannak a társadalomban jelenlevő előítéletekkel (KeRESZTES-TAKÁCS - LENDVAI - KENDE 2016), így a legtöbb örökbefogadásban a származás teljes mértékben bizonytalan. Előfordul az is, hogy az ügyintézők a rendelkezésükre álló információk alapján - név, rasszjegyek - azonosítanak romának egy gyermeket (BoGÁR 2011) és ennek megfelelően ajánlják a megfelelő párnak. Bevett gyakorlat, hogy ha többen visszautasítják a gyermeket a beazonosított rasszjegyek alapján, a vélt cigány származása miatt - hiszen az is cigány, akit a nem cigány környezete annak tart (LADÁNYI 1997) akkor onnantól kezdve már az ügyintézők is úgy „,kezelik” és olyan örökbefogadásra várónak ajánlják fel a gyermeket, aki nem tett származási megkötést.

A többségi társadalom ítélkezik a külső jegyek alapján, akár roma az illető, akár csak annak látszik. Az örökbe adható gyerekről csecsemőkorában nem lehet látni később hogyan fog kinézni és hogyan fogja őt látni és megítélni közvetlen környezete. A ma roma, vagy romának kinéző gyermeket örökbefogadó szülők tapasztalják, hogy a környezet súlyosan ítélkező és megbélyegző (SzILVÁsı 2005), hiszen a többségi társadalom kétharmadában bevallottan él valamiféle negatív kép a romákkal szemben (SZÉKELYI - ÖRKÉNY - CSEPELI 2001).

Egy 2013-as budapesti, örökbefogadásra várakozók közötti felmérés szerint a jelentkezők 66\%-a tesz származási kikötést (NEMÉNYI - TAKÁCS 2015) - vagyis nem vállalnak a saját etnikai hátterétől eltérő etnikumú gyermeket, így roma gyermeket sem -, de az örökbefogadásban dolgozó és a témában jártas szakértők becslései szerint a tényleges elutasítók aránya ennél magasabb lehet. Összességében körülbelül az örökbefogadásra várakozók 80-90\%-a elutasítja, hogy roma gyermeket fogadjon örökbe (KERESZTES-TAKÁCS - NGUYEN 2017). A rendszer paradoxona, hogy hivatalosan nem kérdezhetnek rá arra, hogy elfogadnak-e roma gyermeket, ugyanakkor szerepel egy „egyéb megjegyzés” rubrika az ürlapon, ami alkalmas ezen preferencia rögzítésére (BOGÁr 2011), ugyanígy, ahogy hivatalosan nem tarthatják nyilván a gyermekek etnikai hátteréről szóló információkat sem. Az örökbefogadásra váró szülők nagy része, akik elutasítják, hogy roma gyermekük legyen, leginkább a környezetet teszik felelőssé, vagy a roma kultúrához való viszonyukat említik az elutasítás okaként, de sokan közülük vállalják azt a véleményüket, hogy a romák „,kedvezőtlen” genetikáját szeretnék elkerülni (BoGÁR, 2011). Az örökbefogadó szülők másik, kisebb csoportja a roma gyermeket elfogadó örökbefogadó szülők. Számukra az eddigi nem megfelelő felkészítés, az előítéletekkel való találkozás és az azzal való megküzdés a fő probléma, hiszen interetnikus örökbefogadás esetén az örökbefogadás ténye - ami bár a legtöbb esetben nem titok, de családi ügy - láthatóvá válik és így a szociális stigma tovább mélyülhet (Maldonado 2006; Yngvesson 2010; Miall, 1996). Ezáltal, hogy a hagyományos család percepciója biológiai köteléket feltételez, könnyebben megkérdőjeleződhet a család legitimitása és hitelessége. 
Évről évre nő az örökbefogadásra várakozók száma, valamint kismértékben az örökbefogadások száma is növekszik. (KSH - örökbe.hu², 2016) Magyarországon évente kb. 700 gyermeket fogadnak örökbe, akik többségének bizonytalan a származása, ill. közülük sokan, vélhetően vagy tudottan, cigány származásúak. Így az interetnikus örökbefogadó család egy egyre inkább előtérbe kerülő családkonstrukció, amely a hazai viszonyok között zömében a roma gyermekek nem roma szülők általi örökbefogadását jelenti (SzILVÁsı 2005). Első kutatási lépéseink során azonban rögtön kiderült, hogy nem megismerhető adat az örökbefogadott roma gyermekek vagy interetnikus családok száma, mivel az örökbefogadási rendszerben nem szerepelhet információ a gyermekek etnikai származásáról, és hivatalosan nem is kérhető gyermek örökbefogadásra, származás alapján. Azon kívül, hogy ez nem lenne etikus, mint láthattuk, számos esetben nehéz is megállapítani a származást.

\subsection{Az interetnikus örökbefogadás által létrejött család}

Az örökbefogadás alapjaiban rengeti meg a családdal kapcsolatos elvárásokat, miszerint a család nem biológiai egység, hanem társadalmi konstrukció. Az így keletkezett család sok esetben megtöri az etnikailag homogén hagyományos modellt, így szociálpszichológiai szempontból különösen érdekes, hogy milyen identitáskonfliktusok adódhatnak abból, ha az örökbefogadással létrejött család szereplői különböző etnikai hátterűek (FISHER 2003).

Míg régebben az észak-amerikai és európai országokban próbáltak külsőleg és belsőleg is minél inkább az örökbefogadó szülőkhöz hasonlító gyerekeket örökbe adni, hogy ne legyen feltűnő a biológiai kapcsolat hiánya, addig mára már nem ez a „,megtervezett rokonság” - „kinship by design" - a jellemző (HERMAN 2002 in NEMÉNYI - TAKÁCS 2015), hanem nő a nemzetközi és interetnikus örökbefogadások aránya (HoKSBERGEN 1998 in NEMÉNYI - TAKÁCS 2015).

A nemzetközi szakirodalom leginkább ,transracial” családoknak (GOAR - DAVIS - MANAGO 2016; YNGVESSON 2010; LANCASTER - NELSON 2009) hívja ezeket az új típusú „,ársadalmi” egységeket. A téma és a jelenség újszerüségét tekintve azonban csak kevés hazai szakirodalom foglalkozik ezzel a családmodellel, de Neményiék (2015) az örökbefogadás és diszkrimináció témakörében végzett kutatásukban, már az interetnikus család kifejezést használják erre a családkonstrukcióra.

Az interetnikus örökbefogadás kevésbé elfogadott, mint az örökbefogadás általában, és az örökbefogadott gyermekkel és azon belül a roma gyermekkel kapcsolatban élnek azon sztereotípiák és elvárások, miszerint a biológiai családjukkal felnövekvő társaikkal szemben hajlamosabbak devianciára, hálásabbnak kell lenniük szüleiknek, valamint kevésbé boldogok (KERESZTESTAKÁCS - NGUYEN 2018). Az örökbefogadó szülők irányába egyrészt pozitívabb a kép, a környezet hajlamosabbak őket melegszívűbbnek és barátságosabbnak megítélni, de ezt füszerezi az együttérzés és a szánalom érzete (összehasonlítva a nem örökbefogadó szülőkkel), és ez a viszonyulás kiemelten megjelenik a roma gyermeket örökbefogadók esetében. A társadalom viszonya alapvetően ambivalens az ilyen családok iránt. A magyar társadalomban megtalálhatóak azok a sztereotípiák

\footnotetext{
${ }^{2}$ https://orokbe.hu/2017/10/12/2016-os-orokbefogadasi-statisztika/.
} 
és tévhitek az örökbefogadással kapcsolatban, amelyek megalapozzák az interetnikus örökbefogadó családok stigmatizált helyzetét (KERESZTES-TAKÁCS - NGUYEN 2018), amelynek következtében a „másság”, ,idegenség” létélmény alakulhat ki az érintett szülőkben és családokban. A stigma észlelése pedig befolyásolja, hogy mennyire tekintik ezek az örökbefogadó szülők családjukat „,igazi”-nak. Továbbá kulcsfontosságú szerepet tölt be e családok életében a romaellenes közhangulat és ennek a megjelenése a családi közegben. Az interetnikus örökbefogadás esetében mérvadó az eltérő rasszjegyek láthatósága, nyilvánvalósága a kívülálló számára. Az örökbefogadott roma gyermek értelemszerűen megélheti a másságot. Ebben a megélésben az örökbefogadó szülőnek rendkívül fontos lehet a szerepe: hogyan segíti ezt értelmezni, ezzel megküzdeni. Az interetnikus családban nem feltétlenül csak az örökbefogadott nézőpontjai és a társadalmi sztereotípiák jelennek meg az identitásépítés folyamatában, hanem az örökbefogadó szülő romaképe is, amely lehet hasonló vagy karakteresen más is a szélesebb társadalom sztereotípiáihoz képest.

Az interetnikus örökbefogadási gyakorlat sokak által támogatott és még a társadalomban fellelhető rasszizmus leküzdésének módjaként is felfogható, ugyanakkor olyan hangok is hallhatók - elsősorban az etnikai kisebbséget képviselő szakemberek körében -, melyek a szülőtől eltérő etnikai hátterű gyermekek identitásfejlődésének esetleges zavarait valószínűsítik (JENNINGS 2006 in NEMÉNYI 2015). Ezért adott a kérdés mind a szülők, mind a szakemberek részéről, hogy hogyan kell foglalkozni a gyermek etnikai identitásával, milyen tartalmakat érdemes hozzárendelni?

\subsection{Identitás és etnikai identitás}

Véleményünk szerint a kutatók is számos esetben bizonytalanok az „identitások” és „identitás” fogalmai között. Nyilvánvalóan nehézkessé tenné a szöveget, ha mindig úgy fogalmaznánk, hogy „olyan identitások kialakítását szükséges támogatni, amelynek része a roma csoporthoz való tartozás is". Világossá kell tenni, hogy amikor roma identitásról beszélünk, csak és kizárólag egy ember, egy egyszeri személyiség identitáskonstrumának arról az egy szeletéről szólunk, ami a roma csoporthoz való lehetséges tartozásáról szól, és ez a kapcsolat is nagyon sokszínű lehet. Míg az örökbefogadó szülők életkoruknál fogva már kiérleltebb identitáskonstrukciót hordoznak, addig az örökbefogadott, főként 0-3 év közötti, ,,vélhetően” roma származású gyermekeik nem rendelkeznek még határozott önképpel, sem valamilyenfajta roma identitástudattal. A tinédzser korú gyermekek intenzív identitáskonstruálási folyamatukba már szerepet kaphat a cigányságukhoz füződő viszonyuk, melyet kezdetben a szülők romákról való percepciója, később a közösségi behatások befolyásolhatnak.

Az identitás önazonosságot jelent, ami feltételez egyfajta állandóságot, ugyanakkor ennél komplexebb konstrukció, melyet a környezeti tényezők befolyásolhatnak, így a változás, illetve a kontextualitás is jellemzi. Tajfel és Turner szociális identitás elmélete szerint az egyén koherens, megkülönböztető és pozitív identitáskialakítására törekszik. A koherencia nem jelent mást, mint az identitás időben és térben való kontinuitását, vagyis folytonosságát. Az időbeni folytonosság arra utal, hogyan emlékszik az egyén, ki volt a múltban, hogyan észleli magát a jelenben, 
illetve mit gondol ki lesz a jövőben és ezek a megközelítések nem térnek el jelentősen egymástól. A térbeli folytonosság azt jelenti, hogy az egyén különböző szituációkban is önmaga tud maradni, tehát annak ellenére, hogy az egyén különböző helyzetekben eltérőképpen viselkedik, nem gondol önmagára másképp. A koherenciaigénye meggátolja, hogy az egyént teljesen a környezete határozza meg. Az identitás megkülönböztethetőségének tulajdonsága azt jelenti, hogy mindenkinek sajátos, egyedi identitása van, mely csak őrá jellemző és képes saját magát másoktól való különbözőségén keresztül meghatározni, mások ellenében definiálni (OAKES - HASLAM - TURNER 2002).

A reális vagy stabil identitás három tényező harmonikus egyensúlyából konstruálódik: milyennek gondolom én magam, milyennek lát engem a környezetem és a fontos személyek, és mit gondolok én arról, hogy milyennek láthatnak engem (SzÉKELY 2016³). Ha e három szempont egyensúlya felborul, akkor sérülhet az énkép. Erikson identitásképzés modellje (ATKINSON et. al. 2003) összefoglalva kiemeli, hogy az identitás tudati struktúra, amely komplexitásában egyszerre állandóságra is törekszik, de változékony is, amint társadalmi szerepeink változnak vagy a társadalmi megítélés változik. Az etnikai identitás tematikájának szociálpszichológiai vonatkozásai elsősorban a csoportközi viszonyok problémáinak összetevőjeként merül fel (ERős 1993). Tajfel egy szociális idenititás elméletből indul ki (TAJFEL - TURNER 2004), amely szerint van az identitásunknak egy olyan része, mely onnan származik, hogy milyen csoporthoz tartozónak érezzük magunkat és milyen érzéseink vannak ezzel kapcsolatban. Önbecsülésünk jelentős részét ez a szociális identitás adja, pozitív önbecsülés iránti igényből pozitívan értékeljük és viszonyulunk a saját csoporthoz. Ez igaz az etnikai csoportra is. Az egyén etnikai identitásának alakulása mindig egy olyan folyamat eredménye, mely során egy kisebbségi csoporthoz tartozó személy tudatosítja magában az adott etnikai csoporthoz tartozását. Ebben a folyamatban fontos mozzanat, hogy milyen értékek kötődnek ahhoz a csoporthoz, amihez tartozik, hogy ez alapján pozitív vagy esetleg negatív identitást alakít ki a közösséghez tartozó egyén (PHINNEY 1992). Az etnikai identitás nem egy velünk született tudás, hanem a csoportközi interakciók mentén alakul, formálódik. A társadalmi kisebbséghez tartozó csoportoknál több kutató is foglalkozott az etnikai identitás kérdésével, amit Phinney (1996) etnikai identitás modelljével szoktak kapcsolatba hozni. Eszerint az etnikai identitás egy dinamikus, multidimenziós pszichológiai konstruktum, amikor valaki egy bizonyos etnikai csoporthoz tartozónak érzi magát (PHINNEY 2003). A szociális identitásnak egy olyan vetülete, mely azt vetíti előre, hogy az egyén hogyan címkézi magát, az egyén mennyire tudatos a csoporthoz való tartozásban, milyen kognitív tudása van a csoportról és ez viselkedéses szinten hogyan valósul meg (NEMÉNYI - MEssing 2007). Az identifikációs folyamat tudatosodásának három egymásra épülő szakaszát különböztette meg Phinney: a reflektálatlan vagy feltáratlan fázis, a keresés és exploráció fázis, és a beteljesült, elért identitás fázis (SzABÓ et. al. 2012). Az etnikai identifikáció kialakulásának folyamata általában gyermekkorban kezdődik, így érdekes felvetésnek tünik, hogy ez az etnikai identitás hogyan alakul egy nem roma környezetben szocializálódó, de vélt vagy tudottan roma származású gyermeknél, akik a szüleik roma képén keresztül észlelik a cigánysághoz kapcsolt tartalmakat, és azon keresztül alakul ki saját etnikai identitásuk.

\footnotetext{
${ }^{3}$ SZÉKeLY 2016.
} 


\subsection{Roma identitás az interetnikus családokban}

Alapvető kérdés, hogy a nem roma örökbefogadó szülő hogyan tekint „,vélhetőleg” vagy „tudott” roma származású örökbefogadott gyermekére. A szülők a magukétól eltérő, roma csoporttagságúnak tekinthetik gyermeküket és felmerülhet, hogy a nem roma szülőkben élő romakép vagy roma identitás tartalmai és azok megmutatása örökbefogadott gyermekeiknek lehetnek-e olyan természetűek, illetve megtörténhet-e olyan az átadási gyakorlat folyamán, amin keresztül egyfajta „mássá” alakul a gyermek a családon belül. Előfordulhat, hogy az örökbefogadó szülők valamilyen statikus állapotot feltételeznek a roma identitásról és a bennük kialakított képet vetítik rá a gyerekre, akit ezzel akár „távolabb” helyeznek maguktól, de előfordulhat az ellenkezője is, hogy gyermekük roma származása okán magukat kezdik közelebb engedni a roma identitáshoz. Például a szülők a társadalomban is fellelhető klasszikus, egzotizált romaképhez hozzárendelik, hogy a cigányok jól táncolnak, mint egy állandó, statikus ,jellemzője” a roma létnek és emiatt gyermeküket roma táncházba járatják és ez akár a szülők identitására is hatással lehet egyes helyzetekben. Az identitás, így a roma identitás is dinamikus, konstruált, az elképzelt statikussal szemben. Így az interetnikus családban nevelkedett gyerek - és idővel akár a szülők is az identitásválasztás szabadságát élhetik meg egy olyan ideális társadalomban, ahol egy személy életében identitás-skálák képzelhetőek el (FEISCHMIDT 1997). Roma gyermekekkel kapcsolatosan különösen fontos megemlítenünk, hogy sok esetben látható kisebbségről van szó, így az identitásuk a környezet visszajelzési alapján is konstruálódik, nem úgy, mint azokban az esetekben, ahol önmeghatározás alapján az egyén döntheti el, hogy vállalja-e éppen azt az identitását vagy sem (NGUYEN 2012).

Az is fontos kérdés, hogy az előítéletekkel sújtott kisebbségi csoport tagjai mennyire érzékelik a csoport egészére rásütött bélyegeket és mennyiben befolyásolják a csoport egészére ráhúzott tulajdonságok az egyén tényleges személyiségét és tulajdonságait. A folytonos identitásfenyegetettségben roma identitásuk milyen irányba fejlődik, mennyire érzik úgy, hogy el kell rejteniük azt. Azokban az örökbefogadási gyakorlatokban, ahol a szülők nem vállalnak roma gyermeket, de a bizonytalan származású örökbefogadott gyermekükön később felbukkannak a szülők által „nemvárt” rasszjegyek, vagy felnőttkorban a biológiai gyökerek megtalálásakor szembesül az örökbefogadott esetleges roma származásával és nem elfogadó környezetben nevelkedett, identitásválságot élhet át (SzÉKELY 2016). Persze ezekben a családokban az is kérdés, hogy aki mereven elutasítja a másságot, az hogyan tud megküzdeni azzal a - bár lehet, hogy sok esetben nem látható, de - nagyon is létező mássággal, amit maga az örökbefogadás jelent (SzILVÁSI 2005).

A biztos identitás kialakítása kisebbségi csoport tagjaként még nehezebb, hiszen sokféle társadalmi elutasítással találkozik, melyek óhatatlanul is nyomot hagynak az egyén saját maga megítélésben. Ezért is fontos az örökbefogadott roma gyermekek biztos identitásának kialakítása és annak segítése, hiszen annak hiányában nehezebben épül ki a bizalom, az önértékelés alacsonyabbá válik, illetve a megküzdési stratégiák torzulhatnak (PICKET - GARDNER 2006; CATANESE TICE 2006). A csoporthoz tartozás szubjektív pozitív érzetei, a büszkeség, öröm, elégedettség, a saját csoportunk preferálása, alapvető emberi motívum (TAJFEL 2004), mely a pozitív szilárd identitás eléréshez nélkülözhetetlen. A roma kultúra, a nyelv, hagyományok és szokások megismerése mind olyan elemek, melyek megismerése a pozitív identitás kialakításához hozzájárulhatnak, ezek erősítése elősegítheti, hogy a roma létüket, identitásukat pozitívan éljék meg a csoporttagok (NGUYEN 2012; PÁlOS 2010). 
Releváns kérdésnek tünik az is, hogy a roma identitás és átadásának kérdése a szülőkben mennyire merül fel és ezt mennyire befolyásolja a szakértők, a szervezetek által gerjesztett dilemmák az általuk szervezett reflexiós képzések során, illetve az önsegítő csoportokban a témakörök meghatározásakor. Ugyanis a roma identitás meghatározásának nehézségeit és komplexitását körbejárva úgy tűnik, a roma identitás és annak tartalma nem világosan tisztázott. Ahogy már előzőleg utaltunk rá, a közbeszédben a szituációtól függően, de akár egy szövegen belül is keveredik a fogalomban a teljes identitásra vonatkozó vagy a részidentitási elem képe, ezért szükségesnek tartottuk felmérni, hogy mit gondolnak róla az érintett szülők.

Emellett egy másik kérdés is megjelenik: amennyiben az örökbefogadó szülők felkészültek, hogy egy számukra meghatározhatatlan származású gyermeket fogadjanak örökbe - és tisztában vannak vele, hogy nem lehet egyértelműen romaként identifikálni, és nem bízzák magukat a rasszjegyek és nevek „útmutatására” -, következtethetünk-e arra, hogy csak és kizárólag a társadalom percepciója miatt „,kénytelenek cigánynak tartani” gyermeküket és csupán a társadalmi kényszer miatt szükséges az interkulturális vagy interetnikus létmódot megélniük?

Amikor az örökbefogadó szülök tudatosan kezelik gyermeküket valamilyen okból és formában romaként, megteremtik a lehetőséget a kultúrák találkozására. De nem két, egymástól valamilyen mértékben független kultúra találkozik a családon belül, hanem a szülők kultúrája és a szülők által elképzelt roma kultúra találkozási terepévé válhat a család. Tehát a gyermek roma identitását - mely a teljes identitásának egy „szelete” - a szülő roma identitásának percepciójának implicit vagy explicit átadása alapozza meg. Mindez arra enged következtetni, hogy az örökbefogadó szülők és a „vélhetően roma származású” örökbefogadottak kiemelten reflexív és szenzitív térben mozognak az etnikai származással kapcsolatos identitás kialakításának folyamatában. A valamilyen etnikai csoporthoz tartozás beépítése az identitásba ugyanis még komplexebbé, nehezebbé teszi az identitásépítési folyamatot (PÁLOS 2010).

Erre a folyamatra további nehéz terhet ró a növekvő romaellenesség, amely ma a „társadalom minden rétegére jellemző nyílt formában jelenik meg, és nem függ össze azokkal a háttértényezőkkel, amelyek alapján korábbi kutatások megkülönböztették egymástól az előítéletes és kevésbé előítéletes embereket." (KereszTES-TAKÁCS - LENDVAI - KENDE 2016). A szülők sokszor azzal a dilemmával találhatják magukat szembe a fentiek ismeretében: ki tudják-e, ki lehet-e mondani, hogy örökbefogadott gyerekük cigány. Rendben van-e az, ha azért mondják ki, mert a TEGYESZ, egy alapítvány vagy az örökbeadó azt állította, vagy egyszerűen erőteljesen barna vonások jellemzik és ha kimondják, hogy a gyermekük cigány, akkor rálépnek-e egy szövevényes útra a romaidentitás kialakítása kapcsán.

Véleményünk szerint, mivel az identitásnak és az etnikai identitásnak ilyen erős a konstruált jellege, egy „fluid” viszonyítási rendszer alakulhat csak ki, aminek keretein belül nagyon nehéz kapaszkodókat találni, például, hogy mit is kezdjenek a roma származás vagy identitás témájával az örökbefogadók és gyermekeik. Ebben a helyzetben kemény döntések meghozatalára kényszerülnek, amelyek szinte csak szituatívak, egyéniek tudnak lenni az egyes személyek és családok esetében. Természetesen az örökbefogadói gyakorlat és a sürüsödő kutatások igyekeznek támpontokat, univerzálékat felmutatni, mint például, hogy ne legyen tabu a származás és nyíltan beszéljenek erről az örökbefogadó szülők gyermekeikkel. Ugyanakkor az továbbra is kihívást jelent, hogy 1) milyen származásról beszéljenek a szülők a gyerekkel és 2) a származási kérdések ilyen erős 
társadalmi sztereotípiák által meghatározott természetével mit tud alkalmazás szintjén, a gyermeknevelés során kezdeni a továbbiakban a szülő. Az egyik ilyen tanács a pozitív romakép megerősítése a gyerekben. Azaz, ha már ilyen előítéletes a környezet és a konstruált romakép ennyi negatív tartalmat hordoz, akkor úgy tud jól boldogulni a gyerek ebben a világban, ha pozitív énképének megerősítésébe beépítik a szülők a pozitív romaképet is (PÁlos 2010). Viszont, ha az örökbefogadott gyermek neve nem utal cigány származásra, hisz megmásították vagy nem erősek a rasszjegyei, akkor a társadalom sem fogja romának nézni. Megint felmerülhet tehát a kérdés, hogy mit kezd a szülő ebben az esetben az amúgy nem cigánynak kinéző gyermeke roma identitásával? Pálos (2010. 61.) kiemeli, hogy ,... nagyon fontos szem előtt tartani, hogy bármilyen megoldási kísérlet (akár pozitív, segítő szándék által vezérelt), mely a cigány származásúakat egységesen kezeli, eleve elhibázott, és útjában áll annak, hogy megtalálják saját, egyéni - etnikai és személyes - identitásukat..."

\section{A kUtatás}

Központi és vizsgálandó elemnek az előzetes szakértői és szülői interjúink, valamint a szakirodalom feldolgozása alapján, a roma identitás témakörét választottuk ki, mivel véleményünk szerint a legtöbb dilemmát és kérdést ez az aspektus vetette fel mind szakértői, kutatói és szülői részről is. A kutatásban nagy hangsúlyt kapott a nem roma örökbefogadó szülők percepciója a roma identitásról, az átadási lehetőségekről örökbefogadott cigány gyermekeik részére, ennek szükségszerűségéről és technikáiról. Mit jelent a csoport tagjainak az interkulturális örökbefogadói helyzet, hogy a gyermekük vélhetően roma és maga a roma identitás. Ez alapján az alábbi kutatási célokat és felvetéseket fogalmaztuk meg:

1. Felvetésünk szerint a roma gyermeket örökbefogadó nem roma szülők nagy része a roma identitást pozitívan tüntetik fel és egyfajta romanticizált, általánosságban romákhoz társított pozitív sztereotípiákkal írják le, ellensúlyozva ezzel a társadalomban jelen lévő romákkal kapcsolatos negatív sztereotípiákat.

2. Ezzel párhuzamosan úgy gondoljuk, hogy legkevésbé valószínű, hogy a társadalomban jelenlévő negatív sztereotípiákat kapcsolják a roma identitáshoz, hiszen alapvetően a legelfogadóbb személynek tekintjük a célcsoportunkat, aki a társadalmi távolságot mérő skála (BABBIE 1998) legfelsőbb szintjét „teljesíti”, azaz elfogad családtagjának egy roma személyt.

3. Mivel feltételezéseink szerint az örökbefogadó szülők nagyobb százaléka funkcionál romantizáló romakép alapján, valamint, ha figyelembe veszik az elterjedőben lévő és univerzálisnak tűnő szakértői ajánlásokat, akkor a szülők igyekeznek gyermekükben pozitív romaképet kialakítani, melyek eszközéül leginkább a roma művészeti elemeket választják.

4. Véleményünk szerint a roma identitás közbeszédben való nem tisztázott fogalmi keretei miatt a szülők a személy teljes identitását értik roma identitás alatt és nem csak azt a szeletét, ami a roma csoporthoz való viszonyáról szól. Emiatt bár többen úgy gondolják, hogy nem fognak tudni összetett cigány szimbólumrendszereket, attitűdöket, valóságértelmezési utakat, azaz „,cigány identitást”, ,cigány kultúrát” átadni az örökbefogadott gyerekeiknek, hisz ők maguk nem romák, viszont meg tudják őket ismertetni bizonyos roma kulturális elemekkel. 


\section{A vizsgálat menete}

A vizsgálat az ELTE Pedagógiai és Pszichológiai Kar Kutatás Etikai Bizottság által kiadott kutatásetikai engedéllyel rendelkezik. Az online kérdőív első oldalán meg kellett jelölniük a kitöltőknek, hogy hozzájárulnak-e a kutatásban való részvételhez, illetve fontos kitétel volt, hogy csak abban az esetben töltse ki a kérdőívet, ha biztosan vagy vélhetően roma származású gyermeke van. A kérdőívcsomagot online formában tettük a kitöltők számára elérhetővé. Az online kérdőív elérhetőségét az örökbefogadást közvetítő hét, valamint örökbefogadás segítésével foglalkozó két nagyobb civil szervezetek levelezőlistáján és közösségi oldalán, a roma gyermeket örökbefogadó szülők által létrejött klub levelezőlistáján, valamint a közösségi oldalak örökbefogadással kapcsolatos tematikus csoportjaiban is közzétettük.

\section{A minta}

A kérdőívet összesen 153 roma gyermeket örökbefogadó szülő töltötte ki, melyből 133 a nő (86,93\%) és $20(13,07 \%)$ a férfi kitöltő. A kitöltők életkorának átlaga 42,93 (Min = 27, Max = 63 év) év. A kérdőívünk a demográfiai háttérváltozókra is tartalmazott kérdéseket, mely szerint a kitöltők életkora és neme meghatározása mellett, olyan adatokat kértünk el, mint a lakóhely (főváros 47,1\%, fővároshoz közeli kistelepülésen vagy agglomerációban 18,3\%, megyeszékhely 9,2\%, vidéki kisváros 10,5\%, falu/község 13,7\%, egyéb 1,4\%), iskolai végzettség (szakiskola, szakmunkásképző 5,9\%, érettségizett 4,6\%, OKJ 5,2\%, föiskolai BA 27,5\%, egyetemi MA 46,4\%, doktori fokozat vagy annál magasabb 10,5\%) és anyagi helyzet (átlag alatti 8,5\%, átlagos 52,9\%, átlag feletti 38,5\%). Ezeken kívül a válaszadók családi állapotát (77,1\% házas, 2,6\% kapcsolatban él, $12,4 \%$ egyedülálló, 6,5\% elvált, 1,4\% egyéb) is felmértük. Az alapstatisztikákon túl ezen minta esetében fontosnak tartottuk felmérni gyermekeik számát (69,9\% egy gyermek, 25,5\% két gyermek, 3,9\% 3 gyermek, 0,\% 4 gyermek), illetve, hogy milyen életkorban kerültek a családhoz (átlag 1 éves kor, $\min =0, \max =5$ év) és melyik szervezeten keresztül (63,3\% TEGYESZ, 26,1\% Gólyahír Egyesület, 3,3\% Fészek Alapítvány, 3,3\% Magánutas, 5,9\% egyéb) a gyerekek.

Azt fontos megemlíteni, hogy feltehetőleg több ezer interetnikus örökbefogadó család van, így ehhez képest jelen minta csekély számnak tűnhet, ugyanakkor a téma érzékenységét és szük fórumát tekintve mégis elégedettek lehetünk a mintaszámmal és az eredmények informatív leírásai lehetnek a csoportnak. Az eredményeket ugyanakkor torzíthatja, hogy a kérdőív kitöltésének felhívására aktívabban reagálhattak azok a szülők, akik eleve motiváltabbak gyermekük roma mivoltának megélésében.

\section{Módszertan és mérőeszközök}

A roma gyermeket örökbefogadó szülőknek szánt kérdőívcsomag több mérőeszközt is tartalmaz, de jelen tanulmányban csak a roma identitással kapcsolatos kérdésekre adott válaszokat elemezzük. Például: „Ön szerint létezik-e általában vett roma/cigány identitás?” vagy „Ha meg tud határozni általánosságban roma/cigány identitáselemeket, amelyek Ön szerint átadhatóak örökbefogadott roma/cigány gyermekének, akkor milyen módon próbálja ezeket átadni?”. A kérdések zárt kérdések voltak, többségüknél több válaszlehetőséget is bejelölhettek, de emellett biztosítottunk helyet az egyéb megjegyzésekre is. A kérdőív roma identitás részét egy nyitott kérdéssel kezdtük, az alábbiakként: „Mit ért roma/cigány identitás alatt, milyen tartalmakat köt hozzá?”. 


\subsection{A roma identitásról alkotott percepciók}

Az összmintából 97-en adtak számot arról, mit jelent számukra a roma identitás. A szabadon megfogalmazott válaszokat két egymástól független kódoló kategorizálta, majd az eredmények összevetése után átfogóbb kódcsaládok alá vontuk és így készült el a bemutatásra kerülő végleges struktúra, mely alapján végezzük a tartalomelemzésünket. (1. ábra)

Ahogy feltételeztük az identitásról való statikus kép és annak gyakorlati és „,kézzel fogható” volta miatt leginkább a kultúra és hagyomány téma köré épült a kitöltők asszociációja (összesen 69 említés), ${ }^{4}$ valamint az ehhez kapcsoló „, szokások” említése (8) is megjelent. Itt leginkább deskriptív módon, de egyértelmüen a „roma kultúra” fordult elő (33 említés), ugyanakkor az általánosságban vett kultúra további elemei is említésre kerülnek. Bár a beás nyelv a veszélyeztetett nyelvek közé tartozik, a romani nyelv használati területe pedig csökken (FORRAY - ORSÓs 2016), mégis nagy arányban jutott eszükbe kitöltőknek a ,nyelv” identitásformáló ereje (NGUYEN 2012) (12 említés). A zene és a tánc is (11 említés), mint a romákhoz köthető pozitív sztereotípia deskriptív módon került említésre, így kerültek a kultúra kategóriába. Bár tisztában vagyunk azzal is, hogy a jelenlegi felosztásban kultúra kategóriához sorolt elemek egy részét a sztereotípia kategóriához is társíthattuk volna és sok esetben akár átfedésnek is tünik, ugyanakkor figyelembe vettük, hogy csak felsorolásként asszociálnak rá, vagy az egyénhez kapcsolódó formában fogalmazzák azt meg (pl. zene vagy zenei érzék).

Feltételeztük, hogy a válaszadók többségének asszociációiban megjelennek a társadalomban általánosságban fennálló pozitív sztereotípiák (összesen 41 említés), melyek leginkább a készségek és az attitűd témák köré épültek. A család szeretete (11 említés) és a muzikalitással (9 említés) kapcsolatos említések gyakorisága hűen tükrözi a társadalomban fennálló romákkal kapcsolatos pozitív sztereotípiákat, melyeket a szülők akár implicit akár explicit módon projektálhat a gyermek felé. A köznyelvben szintén gyakran a romákhoz társított erősebb temperamentum (8 említés) és valamelyest a szabad élet és a romák sok esetben irigyelt szabadsága (7 említés) is a roma identitáshoz kapcsolódik. A ,nyitott” és , közvetlen” hozzáállás és a ,jó kommunikáció” is bár kis számban (1-1 említés), de mint pozitív romasághoz társított tulajdonságok is gyarapítják a roma identitásról alkotott sztereotípiákat. Véleményünk szerint többek között ezek azok a kategóriák, amelyek legerősebben képviselik a társadalmi sztereotipizálás jegyeit, azaz a kitöltők többsége is hajlamos a roma identitást a magyar általános romaképpel azonosítani, még ha inkább pozitív jelzőket is soroltak fel.

Bár kevés említéssel bír (8), de a válaszadások tartalma miatt, mégis különálló kategóriát hoztunk létre stigma és elöitélet elnevezéssel. Az akár negatív sztereotípiaként felfogható felsorolásokról azt feltételezzük, hogy nem gyermekük relációjában, de a roma identitást társadalmi keretbe helyezve asszociálva azonosították ,tanulatlansággal” és ,,munkakerüléssel” a roma identitást (1-1 említés). Minden vizsgálat azt mutatja, hogy milyen széles körüek a cigánysággal szembeni előítéletek (KERESZTES-TAKÁCS - LENDVAI - KENDE 2016) és ezért tartjuk fontosnak ennél a célcsoportnál még kevés említésszám esetén is megjeleníteni ezeket a negatív sztereotípiákat. A romák társadalomban helyzetére utalnak ugyanígy a kisebbségi léttel kapcsolatos említések is (6) (,,olyan társadalmi tudatosság, amely számol a kisebbséghez tartozás sajátosságaival”).

\footnotetext{
${ }^{4}$ Az ábrán nem jelenítettük meg külön-külön, de előfordultak még a kultúrához köthető fogalmak 1-1 említésszámmal - melyeket az összeszámlálásnál beleszámítottunk -, mint például a , gasztronómia”, „,müvészet”, , történelem” stb.
} 
0
0
0
0
0
0
0
0
0
0
0
0
0
0
0
0
0
0
0
0
8
0

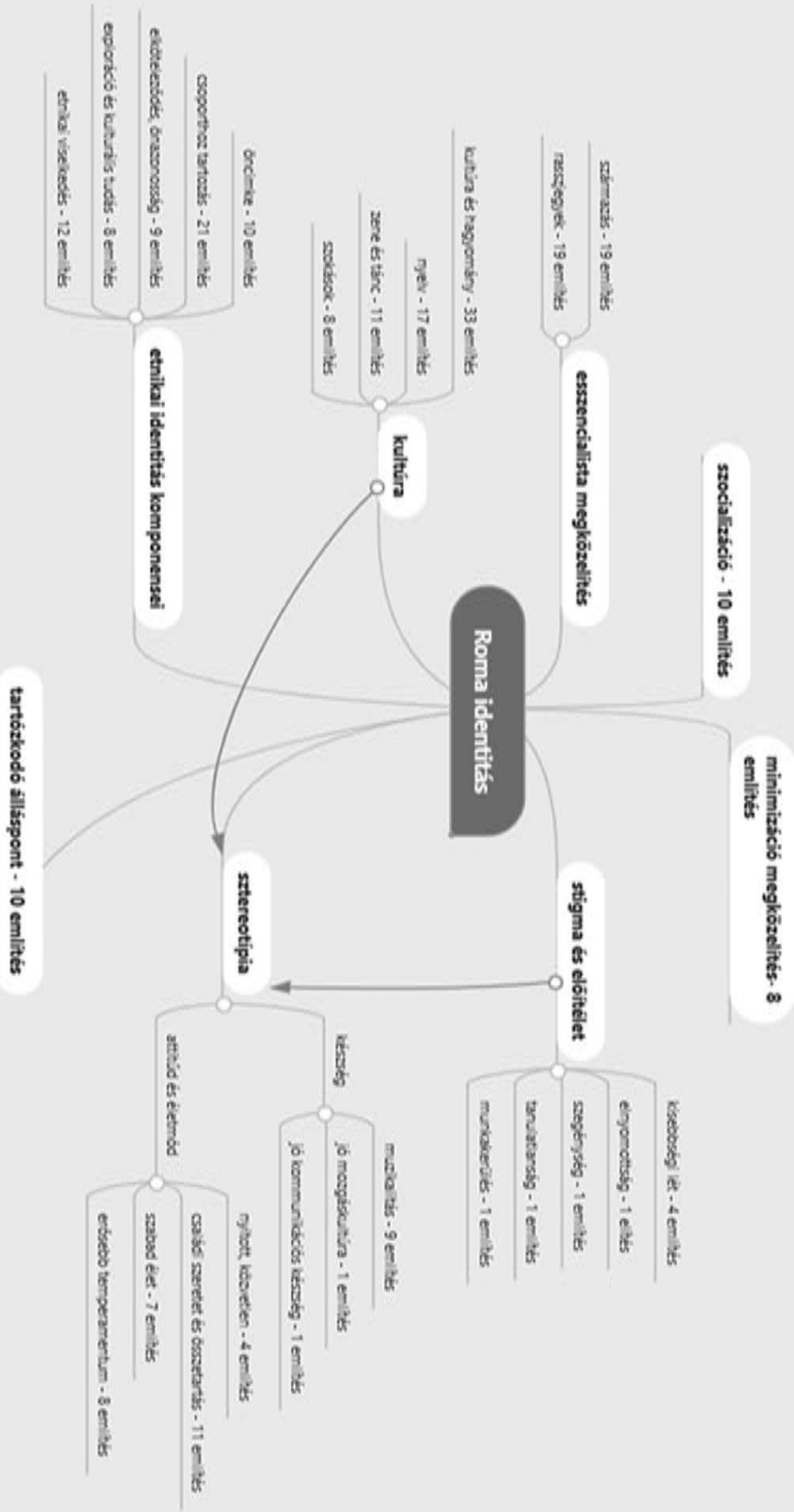


A kitöltők közül 38-an világítottak rá a roma identitás esszencialista voltára, egyfajta velünk született, megváltoztathatatlan és konstans minőségére (BASTIAN - HASLAM 2005). Ezen kategórián belül a kitöltők fele a látható mássággal azonosítja a roma identitást, vagyis a rasszjegyek és külső tulajdonságok alapján (19 említés). A mások által észlelt vagy feltételezett identitás másképp konstruálódik, mint az olyan önmeghatározások, melyekben az egyén döntheti el, hogy mennyiben vállalja azt nyilvánosan (SzABÓ et. al. 2012). Így ezen választ adó kitöltőink gondolhattak arra, hogy roma identitás kialakulásához szükséges és akkor internalizálódik etnikai identitássá, ha az a környezet számára egyértelmű a rasszjegyek alapján és a többség őt romának tekinti.

Az identitás és a származás (19 említés - „,roma szülőktől származik”) köznyelvben gyakran keveredő fogalmak, azonban nem kizárólagosak és nem következik egyértelműen a származásból az identitás és fordítva. A származás természetesen alapja lehet az identitásnak, ugyanakkor az identitás ennél sokkal bonyolultabb és fluidabb konstrukció (SzÉKELY 2016). Az inkább esszencialista értéket képviselő egyének hajlamosak a roma identitást csupán a származáshoz kötni, ezzel azonban kizárhatnak egyéb módon felépülő, ám nagyon is létező roma identitásokat.

Több válaszadó is a szocializációhoz kötötte a roma identitást (10 említés - ,élt roma emberek között”, „roma közegben való szocializáció”), vagyis úgy gondolták, hogy roma identitás csak roma környezetben valósulhat meg és jöhet létre. Itt az identitás kontextuális természetére gondolhattak a kitöltők, hiszen valóban egy roma környezetben felnövő roma fiatalnak egyszerübbnek tűnik a romákkal való azonosulás, ugyanakkor a roma örökbefogadott gyermekek identitását, pont ezért tekintjük egy rendkívül izgalmas konstrukciónak, hiszen véleményünk szerint létrejöhet úgy is, hogy nem roma közösségben nevelkedik.

Igen előkelő helyet foglalnak el az értelmezésünk szerint a roma identitás meghatározásához legközelebb álló említések, melyek a szociálpszichológiai értelemben vett etnikai identitás és annak komponensei és fejlödési szintjei köré épülnek (összesen 61 említés). Az etnikai identitás komponensei közül a csoporthoz tartozás merült fel a legnagyobb arányban (21 említés), melyek olyan válaszokban érhető tetten, mint a ,, közösségi élmény”, , lelki szinten egy közösséghez tartozás érzését”. 12 válaszadó azonosította a roma identitást a roma hagyományok ápolásával, melyet az etnikai viselkedés kategóriába soroltunk. Az öncímkézés kategóriába vettük azokat a válaszokat (10 említés), melyekben a roma identitást a roma önbevallással azonosították, „, aki romának tartja magát”. Az etnikai identitás fejlődésnek szintjeivel kapcsolatos válaszok szinte ugyanannyi említést kaptak (8-9): az exploráció, mikor az egyénnek tudása van az etnikai hovatartozásáról például ,etnikai öntudat”, ,,tudás a roma származásról” és az elköteleződés, mikor azonosul azzal ,,származási csoport elfogadása vagy azzal való azonosulás”. Az etnikai identitás fejlődését Phinney modellje (1992) alapján tehát az exploráció és az elköteleződés mentén vizsgáltuk, valamint annak főbb komponenseit kategorizáltuk. Ezek alapján úgy tűnik, hogy a szociálpszichológiai szempontból vett etnikai identitás különböző megjelenési formái igen nagy arányban, több mint a releváns válaszolók fele említette tehát az összetett identitáskonstrukció ismerete is magasan képviseltette magát a nagyarányú statikus, leíró válaszokkal szemben.

Bennett (1986) interkulturális kompetencia fejlődési modelljének első három szintje az etnocentrizmusé. Ebben az állapotban az egyén vagy felismeri a kultúrákból adódó különbségeket, vagy nem, de mindenképp a maga értékrendjét tartja mérvadónak, a másikat próbálja a maga 
kultúrájához igazítani. Az etnocentrizmus utolsó szakaszát Bennett minimizációnak vagy minimalizációnak nevezi. Az egyén elismeri a különbséget, és bár már nem harcol ellene a becsmérlés vagy a felsőbbrendűség stratégiáival, de kísérletet tesz jelentőségének minimalizálására. A hasonlóságokat annyira túlhangsúlyozza a kulturális különbséggel szemben, hogy ezáltal jelentéktelenné teszi azt. Ezen ideológiák érhetők tetten a következő mondatokban ,,nem tartom lényegesnek”, „nem cigányként, hanem gyerekemként gondolok rájuk”, melyet így minimizáció kategóriának neveztünk el (8 említés).

Tartózkodó álláspont (10 említés) kategóriába az olyan válaszadásokat soroltuk, mikor a roma identitást vonták kétségbe ,,nem hiszem, hogy kell lennie tiszta identitásnak”, ,,nem jellemezhetök azonos identitással". A romaidentitás kétségbe vonása abból is következhet, hogy nincs egy mindenki által egyértelműen ismert, közösen használt tartalma a „roma identitás” fogalmának. A kutatók az egyén roma csoporthoz való dinamikus viszonyát értjük (PÁLOS, 2010), a szülők egy része ezzel szemben azt feszegeti, hogy nincs olyan, hogy általában vett roma identitás, azaz egy minden önmagát romának valló vagy annak tartott személyiségre jellemző roma ,virtus”. Ez utóbbi hangsúlyos elutasításáról szólnak ezek a kétségbevonó mondatok, mely szerint nem lehet, hogy a társadalom kitalál egy „romának kinéző” emberről, gyermekről valami általánosat, ami biztos mindannyiukra jellemző.

Az általánosságban vett roma identitás tartalmának ismertetésén túl fontosnak tartjuk bemutatni, hogy a kérdőív kitöltői között tanulságos megoszlást mutat, hogy mennyire tartják gyermeküket romának - nem roma származásúnak. 41,8\% egyáltalán nem, vagy inkább nem, egyharmaduk (30,9\%) annak is tartja és nem is, a maradék egyharmad (28,3\%) viszont inkább vagy teljesen romának tartja gyermekét. Tehát az örökbefogadó szülők jelentős része inkább nem tartja gyermekét romának, „csak” roma származásúnak - hiszen a kérdőív kitöltésekor kizárás volt, ha nem roma származású az örökbefogadott gyermeke - így nem fókuszál a roma identitás problematikájára. Ez a nagy arányszám kifejezetten különleges vetületére mutat rá a problémának. Megjelenik a származás minimalizálása, vagyis egyfajta antiesszencialista szemlélet a szülők részéről, miszerint az etnikai származás nem eredményez egyenes arányban etnikai identitást is, így valószínű a szocializációs folyamatoknak nagyobb jelentőséget tulajdonítanak és a gyermek szülőkhöz való asszimilációs hatását erősebbnek vélik. A szülők nagyobb része viszont úgy tűnik, hogy kisebb vagy nagyobb mértékben, de a „romaságot” a származáson túl is hozzárendeli a gyermekhez, vagyis családon belüli integrációs akkulturációs stratégia figyelhető meg.

Arra a kérdésre, hogy „Vajon létezik-e általában vett cigány identitás?” a válaszadók többsége, azaz 63,2\%-a igennel válaszolt, míg 19,1\% nem tudja és 17,8\% mond kategorikusan nemet. Az, hogy a kitöltők többségének véleménye szerint van egy körülírható roma identitás, azt feltételezi, hogy az örökbefogadók többsége is a „mainstream” romaképpel szocializálódott és egy adott egzotikus etnikumhoz köt bizonyos általános ismertető jegyeket (LADÁNYI - SzELÉNYI 2000). A maradék közel 20 százalék, aki nemmel válaszolt, valószínűleg hallott már az identitáskonstrukció rétegeiről és tudta azt interiorizálni vagy ezt hozza magával speciális szocializációja miatt. Ugyanakkor érdekes itt a magasan kiemelkedő „nem tudom” válaszok száma is. 


\subsection{A roma identitás átadásának dilemmája}

Ahogy a roma identitás miben léte, úgy annak átadása kapcsán is úgy tűnik, erős kételyek fogalmazódnak meg az örökbefogadó szülők körében. Egyenlő mértékben oszlanak meg a válaszok annak a kérdésnek a kapcsán, hogy „Fontosnak tartja a roma/cigány identitás átadását roma/cigány gyereke(i)nek?", mely során az igen 36,2\%-ot, a nem 37,5\%-ot, a nem tudom 26,3\%-ot kapott. Ez jóval inkább dilemmákat felvető kérdésként merül fel, mint akár a származás megállapítása vagy a roma identitás tartalma, bár ezektől nem függetleníthető kérdés. Attól függően, hogy hogyan konceptualizálják a roma identitást az örökbefogadó szülők, illetve, hogy milyen tartalmakat kötnek hozzá, nagyban befolyásolja az arról való elképzelésüket, hogy ezt át tudják-e adni, szükséges-e, illetve lehetséges-e egyáltalán átadni a roma származású gyermeküknek. Mélyebbre ásva a roma identitás átadásának témakörében, az alábbi kérdéseket tettük fel: Miért lehet szükséges a roma/cigány identitás átadása örökbefogadott roma/cigány gyermekének?; Milyen roma identitáselemeket lát átadhatónak?; Hogyan próbálja ezeket az elemeket átadni?.

Bár az előzetes desk research kutatásaink során a társadalmi előítéletesség merült fel elsődleges motivációnak a roma identitás átadásakor, az eredmények alapján úgy tünik, hogy a szülők sokkal inkább a gyermekük mentális egészségét helyezik előtérbe. Esetükben inkább úgy hangzik a diszkriminációra történő hivatkozás, mint egy megtanult, szükséges, vitathatatlan és így jó hivatkozási alap. A származás miatt érzett büszkeség is főként a diszkriminációval szembeni vagy másság-kezelési stratégiaként merülhet fel, de ez sokadrangú motivációként jelenik meg. A szülők véleménye alapján úgy tűnik, hogy a pozitív romakép kialakítása a legfontosabb, ahol implicit megjelenik a társadalom negatív romaképének ellensúlyozása és erre törekszenek a roma identitás átadás kapcsán. Szinte ugyanennyien értettek egyet azzal is, hogy ez a gyermek teljes identitásához tartozik hozzá, ezért szükséges a roma identitás átadása. Ez a magas arányszám arra enged következtetni, hogy a szülők nagy része a roma identitást nem a teljes identitás, hanem annak egy igen fontos szeletének tekintik (2. ábra).

mivel a vér szerinti szülei cigányok és tovább vigyék a hagyományokat

könnyebben tud nagyobb korában eligazodni a roma világban

könnyebben tud roma társaihoz kapcsolódni

nem szükséges a roma identitás átadảsa

büszke legyen a cigányságára

hozzátartozik a gyermek kiteljesedéséhez

a gyermek fel tudjon készülni arra, ha megkülönböztetés éri

jobban megértse a gyermek a gyökereit

hozzátartozik a gyermek valós, teljes identitásának kialakitásához

pozitiv kép alakuljon ki a gyermekben romaságával kapcsolatban

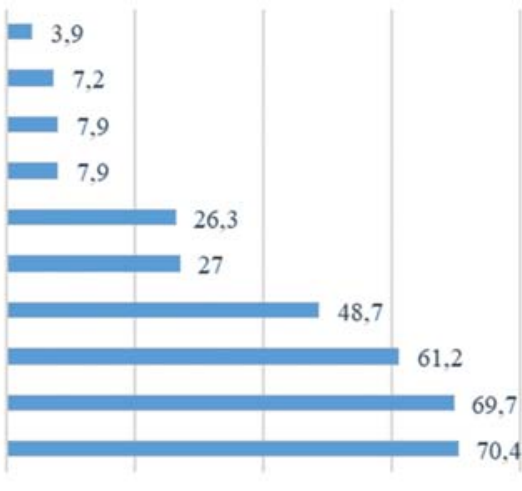

20

40

60

2. ÁBRA Ön szerint miért (lehet) szükséges roma/cigány identitás átadása örökbefogadott roma/cigány gyermekének? (\%) 
A roma identitásra való asszociációk eredményei alapján nem meglepő, ha a romaidentitás átadásnak a módját a szülők több mint fele a roma kultúra értékeinek megismertetésével hozza összefüggésbe. A cigánysághoz kapcsolódó sztereotip készségek, valamint a rasszjegyek pozitív megerősítése jóval nagyobb arányban szerepelnek, mint ahogy az fentebb, a roma identitás tartalmaként megjelent. Összességében ez azt jelenti, hogy a válaszadók kb. 85\%-a megnevez valamilyen roma identitásépítő elemet és annak átadási módját - vagy azt, hogy később fog sor kerülni rá -, ám kb. 15\% elutasítja ezt. Számos egyéni válaszban írják le, hogy vagy megjelölhették volna az összes opciót, vagy teljesen értelmetlen egyáltalán maga a felvetés is, mert pl. a sokszínüséget mutatják be (3. ábra).

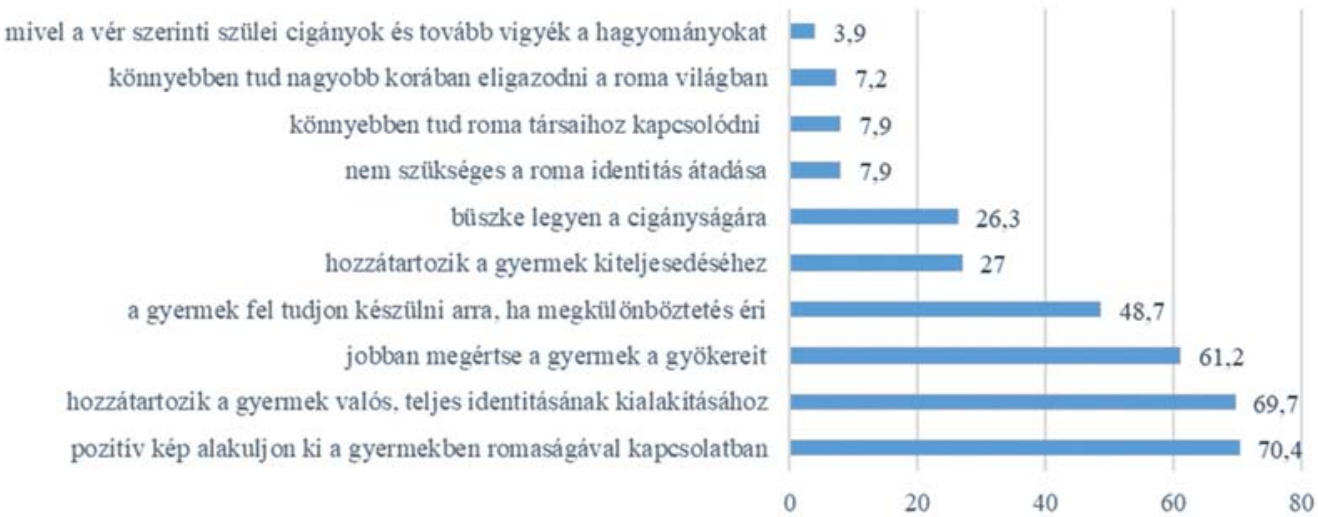

3. ÁBRA Ha meg tud határozni általánosságban roma/cigány identitáselemeket, amelyek Ön szerint átadhatóak örökbefogadott roma/cigány gyermekének, akkor milyen módon próbálja ezeket átadni? $(\%)^{5}$

Mivel az előző kérdésre adható válaszok között szerepelt a cigánysághoz köthető készségek, adottságok pozitív megerősítése - mint szakértői ajánlás is a szülők számára, hogy gyerekükben pozitív romaképet alakítsanak ki, mintegy felkészítendő őket a társadalom negatív sztereotípiáinak elviselésére -, így kíváncsiak voltunk ennek tartalmaira is, hogy a gyakorlatban hogyan jelenik meg a sztereotip tartalmak pozitív megerősítése.

Legnagyobb arányban a külső jegyek megerősítése történik, hiszen ez már egész kiskortól kezdve egy látható tulajdonság. A szakértők is egyetértenek, hogy a fizikai tulajdonságok pozitív megerősítése fontos a kezdetektől, hiszen ekkor még kevesebb az eszközünk arra, hogy beszéljünk gyermekünkkel a cigányságról és ez egy jó alap lehet a későbbiekre nézve. A többi felsorolt válaszlehetőség vagy veleszületetten a gyermek személyiségének a része, vagy a szülő fejében élő romákról alkotott kép miatt kerül megerősítésre, amitől valóban jobb érzéke lesz a zenéhez

\footnotetext{
${ }^{5}$ Csupán néhány fő jelölte meg az alábbi válaszlehetőségeket, így ezeket a diagram nem tartalmazza: valamelyik cigány nyelv megtanítását, a beszélgetést a roma holokausztról választ és a romákkal kapcsolatos tanulmányok folytatását iskolában, egyetemen.
} 
vagy ügyesebben mozog majd, így végül a feltételezett genetikai tulajdonság helyett szerzett tulajdonság is lehet. A gyermek temperamentumával kapcsolatos pozitív megerősítések a szülők negyedénél meghatározó fontossággal bírnak. Vannak ugyanakkor olyanok is, akik ezzel a megoldással nem értenek egyet és ezért csak másképpen, vagy egyáltalán nem szeretnék a roma identitást átadni. Az egyik szülő felhívta a figyelmet az egyik legfontosabb különbségre, miszerint nem a pozitív romaképet, hanem a pozitív énképet kívánják gyermekükben megerősíteni. Van, aki megjegyezte, hogy a felsorolt válaszok sztereotípiák és nem cigánysága miatt jó ezekben a dolgokban a gyermek. Többen megjegyzik, hogy a gyermek tulajdonságait cigányságtól függetlenül pozitívan erősíti meg (4. ábra).

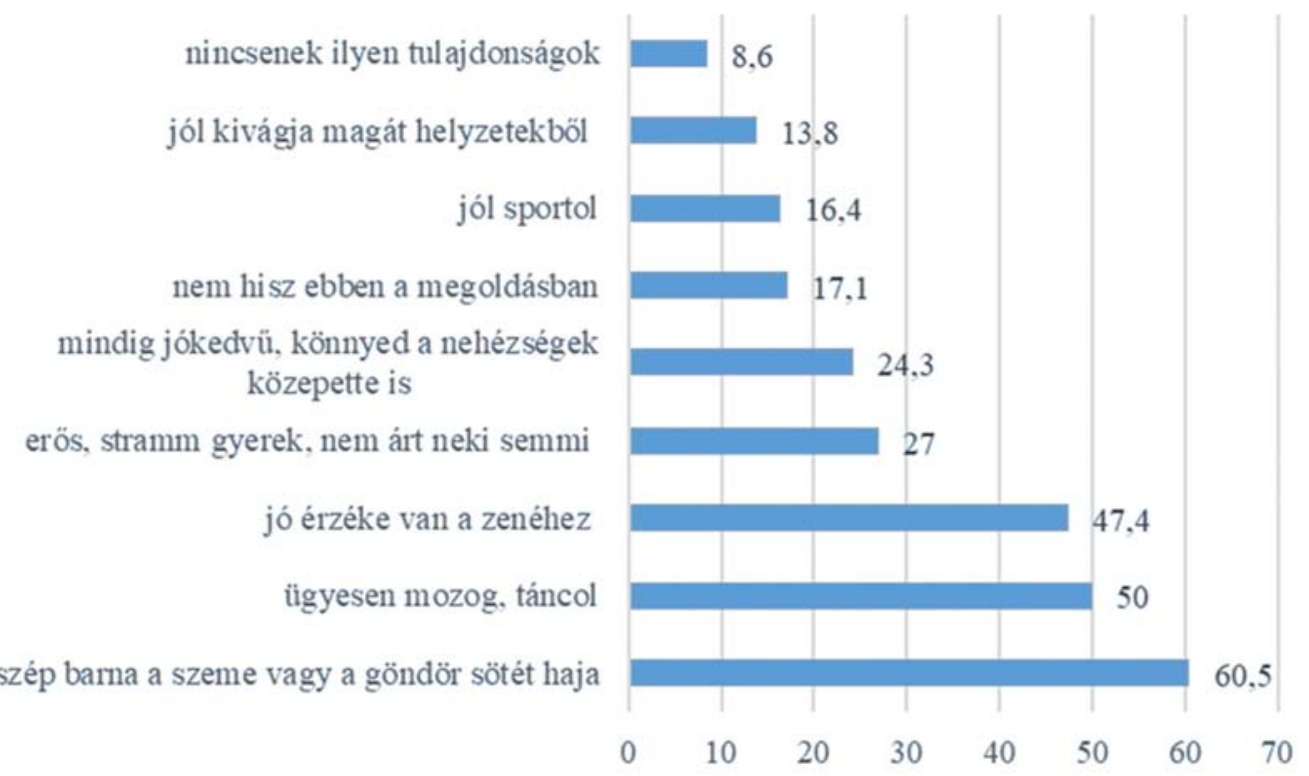

4. ÁBRA Melyek azok a sok esetben roma/cigánysághoz kapcsolt adottságok, készségek vagy fizikai jegyek, amelyeket Ön is megerösit/ene gyermekében a pozitiv romakép kialakitása érdekében! (\%)

Az adatok számunkra azt mutatják, hogy az örökbefogadó szülők nagy része azonosul a roma identitás és átadás gondolatával, vagy legalábbis bizonytalanul keresi benne a helyét. Mikor rákérdeztünk, hogy tervezi-e romaidentitás átadását gyermekének, akkor csupán a szülők egyharmada válaszolt igennel, a további kérdésekre adott válaszok alapján viszont úgy tünik, hogy ennél árnyaltabb a kép. Ez a különbség adódhat abból is, hogy nem feltétlen gondolják roma identitás átadásnak azt a folyamatot, mikor a hétköznapokba becsempésznek egy-egy cigány zenét, vagy mutatnak egy jó példát, hanem roma identitás átadás folyamatán valami egészen speciális „tudás” átadást értenek. Előfordulhat az is, hogy ha keveredik a származás és az identitás fogalma, akkor az inkább esszencialista értékeket valló nem roma származású örökbefogadó szülő hiteltelennek érzi bármilyen szeletét is megosztani, bemutatni a roma identitásnak. 


\section{ÖsSZEGZÉS}

Van egy következetesen megvalósuló jellegzetesség, egy központi összekötő szál, mégpedig maga az interetnikus örökbefogadói család létmódja és az ebből fakadó kérdésekre, kihívásokra történő folyamatos válaszkeresés. Ennek központi kérdése a család és szereplői önmeghatározása, identitása, melynek alapkövét képezi maga az örökbefogadói lét és az ebből fakadó társadalmi megkülönböztetés, illetve, hogy a roma származású örökbefogadott gyermeket cigánynak tartják-e a nem roma örökbefogadó szülők, és ebből fakadóan milyen szocializációs stratégiákat választanak. Kutatásunk arra mutat rá, hogy a többnyire közép- és felsőközép-osztálybeli, fővárosi és környékén élő, értelmiségi örökbefogadók törekednek arra, hogy örökbefogadott cigányszármazású gyermekük harmonikus kapcsolatot tudjon kialakítani azzal a társadalmi jelenséggel, hogy őt a többségi társadalom, ideértve sok esetben akár az örökbefogadó szülőket is, egy általában vett cigány csoporthoz sorolja majd, pozitív vagy negatív sztereotípiákat társítva hozzá. A szakértők az ezt segítő szocializációs stratégiákat „roma identitás fejlesztéseként, átadásaként” aposztrofálják, amelyet egyrészt az örökbefogadó szülők és kutatók is átvettek, ám vegyes fogadtatásra talál az interetnikus örökbefogadó szülők körében. Számos örökbefogadó szülőben zavart okoz a „roma identitás” fogalma és az annak kialakítására tett erőfeszítések megítélése. Emiatt folyamatosan visszaigazolást keresnek a szülők, hisz nem tudják megítélni, mi következik a gyermek cigány származásából, ha következik egyáltalán valami és mi csak korosztályos kihívás a gyermek életében. Kevés örökbefogadó szülő tudja felfüggeszteni az őt befolyásoló társadalmi sztereotípiákat a cigányokkal kapcsolatban, még ha pont ez ellen küzdenek is és csak a szélesebb társadalom diszkriminatív attitüdje miatt tartják fontosnak a témával egyáltalán a foglalkozást. Bár már alapvetés számukra, hogy roma identitást nem tudnak átadni, mivel ők maguk nem romák, de azt a belső konfliktus is feloldásra vár, hogy ők maguk se lássák másnak gyermeküket.

Ahogy azt feltételeztük, a roma gyermeket örökbefogadó szülök összességében tehát hajlamosak voltak deskriptív és statikus módon leírni a roma identitást, akár a kultúrákkal vagy sztereotípiákkal kapcsolatos asszociációkra gondolunk. Ezek akár pozitív sztereotípiaként, illetve az identitás átadásának lehetőséges módjaként is felfogható asszociációk, ahogy azt sejtettük, ezekből szerepelt a legtöbb a roma identitás meghatározásánál. A kognitív elemeknek, azaz a kultúrával kapcsolatos ismereteknek, mint például hagyományoknak, szokásoknak tehát nagy szerepük van az identitásformálásban és a nem roma szülők ezekkel a lehetséges átadási formákkal azonosítják magát az identitás fogalmát is. Ugyanakkor - ahogy feltételeztük is - élnek a szülők fejében pozitív sztereotípiák a romákról, melyet többen a roma identitással vagy annak egy elemével azonosítottak, így a családi mikrokörnyezetükben ezzel is ellensúlyozzák a társadalomban túlnyomó részt fennálló negatívabb sztereotípiákat.

Ezek mellett nagy arányban jelentek meg a mi roma identitás értelmezésünkhöz legközelebb álló, vagyis az etnikai identitás komponensei közé besorolható válaszadások is, mikor a roma identitást az egész identitáskonstrukció egy szeletének tekintik. Ezeken kívül a származás és a rasszjegyek jelentek meg nagy említésszámmal, mellyel a „romaság”, a „roma lét” egyfajta megváltoztathatatlan adottságára hívják fel a figyelmünket. Eszerint, ha valakin „látszik”, vagy származásilag roma, akkor nem kerülhető el a roma identitás létrejötte, tehát újból az identitás statikus tulajdonsága 
kerül előtérbe. Roma gyermeket örökbefogadó szülők vizsgálatakor meglepő eredmény volt - bár a nagyobb kategóriákhoz képest kisebb számban fordult elő - a roma környezet identitásformáló erejéről, a különbségek minimalizációjáról vagy a romákkal kapcsolatos negatív sztereotípiákról olvasni. Ezek - ahogy feltételeztük is - kisebb számban kerültek említésre.

Szocializációs stratégiák szempontjából bár heterogén a csoport, mégis a szülők nagyobb része sztereotípiákra építve tudja csak a stratégiát meghatározni. Közös jelenség, hogy az örökbefogadó szülőknek többsége sztereotip, romantizáló romakép alapján igyekszik gyermeke cigányszármazásához viszonyulni, identitásának kialakításában segíteni, ezzel pedig statikus időbe és térbe helyezi az örökbefogadottat egy idegen konstitúciós folyamat során, aminek antiasszimilációs hatása is van. Romantikus romaképekhez nyúlva kötnek fizikai tulajdonságokat, készségeket, attitűdöket - mint például a rasszjegyek, a jó zenei és ritmus érzék, vivid mentalitás, stb. a cigány származáshoz és igyekeznek ezeket pozitívan megerősíteni a gyermekben. Elfogadva és megelőlegezve továbbá az előítéletes társadalom reflexióit kezelő kényszert, a gyermek - ráadásul - csak vélhetően cigány származásához általuk köthető jegyeket pozitívan megerősítve az ő cigányságát és az arról alkotott képet is erősítik, így akár antiasszimilációs folyamatnak is a tanúi lehetünk. Ahol ez a folyamat nem olyan erőteljes, ott megjelennek a szülők kultúrájának és a cigány kultúra mezsgyéjén létező, vagy önmagukat mindkét csoporthoz soroló identitások.

A megvizsgált identitástartalmak egy része tehát a romanticizált roma sztereotípiákból áll. Láthatjuk, hogy legnagyobb arányban a roma kultúra révén próbálja a szülő gyermekének átadni a roma identitást ám ezáltal ő is résztvevőjévé válik a kultúraápolás egyes elemeinek. Kérdés, hogy a kultúraátadás folyamán, ahogy a gyermekben alakul az etnikai identitása, mi lesz a szülő, addig stabilnak tűnő és meg nem kérdőjelezett többségihez tartozó etnikai identitásával, hogyan hat vissza a családon belüli akkulturációs folyamatokra? A roma mozgáskultúra gyakorlása, roma zene hallgatása vagy egy cigány népmese olvasása, melyen a szülő is aktívan részt vesz gyermeke identitásformálása szempontjából, vajon a saját identitásán elindít-e változást? Hiszen, ha az etnikai viselkedés szintjén változás áll be - vagyis elkezdik ápolni, táplálni a hagyományokat -, akkor az attitüd lényegi tulajdonságából fakadóan húzhatja maga után az etnikai identitás többi komponensét is, vagyis az etnikai öncímkézést, csoporthoz tartozást és az érzelmi aspektust is.

Ahogy az előzőekben rámutattunk, a roma gyermeket örökbefogadók nem kérdőjelezik meg gyermekük cigány származást, inkább ezt elfogadva merülnek fel azok a kérdések, hogy hogyan is kezeljék a legjobban ezt a helyzetet, aminek csak egyik útja lehet a roma identitás átadása, de nem kötelező jelleggel. Ehhez azonban látni kell azt, hogy az etnikai identitás, így a roma identitás is egy ember, egy gyermek identitásának csupán egy szelete.

\section{Felhaszálet IROdAlom}

Atkinson, Rita. L. - Atkinson, Richard C. - Smith, Edward E. - Bem, Daryl. J. - NolenHoeksema, Susan (2003): Pszichológia. Második javított kiadás. Budapest, Osiris Kiadó

BASTIAN BROCK - HASLAM Nick (2005): Psychological essentialism and stereotype endorsement. Journal of Experimental Social Psychology 42. évf. 228-235. DOI: 10.1016/j.jesp.2005.03.003 
Bennett Milton J. (1986): A Develpoemental Approachto Training for Intercultural Sensitivity. International Journal of Intercultural Relations vol. 10. no. 2. 179-196.

BogÁr ZsuZSA (2011). Az örökbefogadás lélektana. Budapest, Ágacska Alapítvány az Örökbefogadásért és a Családokért

Breakwell, Glynis. M. (1993): Social representations and social identity. Papers on social representation vol. 2. no. 3. 198-217.

Brewer, Marilynn B. - Picket, CynthiA. L. (2006): A társas én és csoportidentifikáció: a beolvadás és az elkülönülés motivációja a személyközi és kollektív identitásban. In FoRGÁCs JózSEF (szerk.): A társas én - Az önmegismerés pszichológiája. Budapest, Kairosz Kiadó. 297-316.

Catanese, Kathleenn. R. - Tice, Dianne M. (2006): Az elutasítás hatása az antiszociális viselkedésre: a kirekesztés agresszív viselkedéshez vezet. In KIPLING, D. WiLliAMS - ForGÁCS, JózSEF Hippel, William von: A társas kirekesztés pszichológiája. Budapest, Kairosz Kiadó. 304-312. ERÖs FERENC (1993): A válság szociálpszichológiája. Budapest, T-Twins Kiadó. 150.

Feischmidt Margit (1997): Multikulturalizmus: kultúra, identitás és politika új diskurzusa. In Feischmidt Margit (szerk.): Multikulturalizmus. Budapest, Osiris. 7-29.

FiSHER, AlLEN P. (2003): Still „Not quite as good as having your own”? Toward a sociology of adoption. Annual Review of Sociology vol. 29. no. 1. 335-361.

ForRAY R. KATALIN - Orsós ANNA (2016): Roma jövő Magyarországon. Educatio 25. évf. 4. sz. 516-526. http://epa.oszk.hu/01500/01551/00098/pdf/EPA01551_educatio_2016_4_516-526.pdf. Hozzáférés dátuma: 2018. 05. 31.

Goar, Carla - Davis, Jenny L. - Manago, Bianca (2016): Discursive Entwinement: How White Transracially Adoptive Parents Navigate Race. Sociology of Race and Ethnicity vol. 3. no. 3. 1-17. DOI: $10.1177 / 2332649216671954$

HAVAs GÁBOR - Herczog MÁRIA - NemÉnYi MÁRIA (2007): Fenntartott érdektelenség. Roma gyerekek a gyermekvédelmi rendszerben. Budapest, Európai Roma Jogok Központja

Keresztes-TAKÁcs Orsolya - Lendvai LiLla - Kende AnNa (2016): Romaellenes előítéletek Magyarországon: Politikai orientációtól, nemzeti identitástól és demográfiai változóktól független nyílt elutasítás. Magyar Pszichológiai Szemle 71 évf. 4/2 sz. 601-619. DOI: 10.1556/0016.2016.71.4.2

Keresztes-TakÁcs Orsolya - Nguyen Luu, Lan AnH. (2017): Az örökbefogadás szociálpszichológiai megközelítése: Interszekcionalitás az örökbefogadásban. Alkalmazott Pszichológia 17 évf. 2 sz. 53-69. DOI: 10.17627/ALKPSZICH.2017.2.53

Keresztes-TakÁcs Orsolya - Nguyen Luu Lan Anh (2018 - megjelenés alatt): Stereotypes of adoptive and interethnic adoptive families in Hungary. Alkalmazott Pszichológia 18 évf. 3. sz. örökbe.hu (2016): KSH statisztikai adatok az örökbefogadásról. https://orokbe.hu/2017/10/12/ 2016-os-orokbefogadasi-statisztika/. Hozzáférés dátuma: 2018. 05. 31. 
LADÁNYi JÁNOS - SzELÉNYI IVÁN (2000): „Ki a cigány?” In ForRAY R. KATAlin (szerk.): Romológia. Budapest - Pécs, Dialóg Campus Kiadó. 13-24.

Lancaster, Christy A. - Nelson, K. W. (2009): Where Attachment Meets Acculturation: Three Cases of International Adoption. The Family Journal: Counseling and Therapy for Couples and Families vol. 17. no. 4. 302-311. DOI: 10.1177/1066480709347357

Maldonado, Solangel (2006): Discouraging racial preferences in adoptions. UC Davis Law Review Forthcoming. Seton Hall Public Law Research Paper No. 36.

Miall, Charlene E. (1996): The Social Construction of Adoption: Clinical and Community Perspectives. Family Relations vol. 45. no. 3. 309-317. DOI: 10.2307/585503

Neményi MÁria - Messing Vera (2007): Gyermekvédelem és esélyegyenlőség. Kapocs 6. évf. 1. sz. 2-19.

NEMÉNYi MÁRIA - TAKÁCS JUdiT (2015): Az örökbefogadás és diszkrimináció. Esély 2. sz. 69-96. PÁlos DóRA (2010): „Cigány” identitások nehézségei - Egy önbeszámolókon alapuló vizsgálat tanulságai. Esély 2. sz. 41-63.

Oakes Penelope J. - Haslam, S. Alexander (1994): Stereotyping and Social Reality. Oxford, Blackwell

Pavao, Joyce Maguire (2012): Az örökbefogadás háromszöge. Budapest, Mózeskosár Egyesület Phinney, Jean S. (1992): The Multigroup Ethnic Identity Measure. A New Scale for Use with Diverse Groups. Journal of Adolescent Research vol. 7. no. 2. 156-176.

Phinney, Jean S. (1996): Understanding ethnic diversity. American Behavioral Scientist vol. 40. no. 143-152.

Phinney, JeAn S. (2003): Ethnic identity and acculturation. In K. M. ChUn - P. B. Organista G. MARÍN (eds.): Acculturation: Advances in theory, measurement, and applied research. APA, Washington DC. 63-82.

Picket, Cynthiya L. - GARdner, Wendi, L. (2006) A társas monitorozó rendszer. In Forgács JÓzSEF (szerk.) A társas én-Az önmegismerés pszichológiája. Budapest, Kairosz Kiadó. 304-312.

Szabó MónIKA - NGuYen LuU LAN ANH - SzABÓ ÁGNES - FliszÁr Éva (2012): Magyarországon élő fiatalok többségi és kisebbségi identitása egy kérdőíves kutatás tükrében. In NGUYEN LUU LAN ANH - SzABÓ MóniKa (szerk.): Identitás a kultúrák kereszttüzében. Budapest, ELTE Eötvös Kiadó. 55-91.

SZILVÁSI LÉNA (2005): Örökbefogadás - Identitás - Sajtó - Botrány. Család Gyermek Ifjúság 14. évf. 1. sz. 4-7.

SZÉKELYI MÁRIA - ÖRKÉNY ANTAL - CSEPELI GYÖRGY (2001): Romakép a mai magyar társadalomban. Szociológiai Szemle 11. évf. 3. sz. 19-46. 
SZÉKELY ZsUZSA (2016): Hogyan segithetik az örökbe fogadó szülök a roma gyermekük identitásának a fejlődését? Mózeskosár Egyesület 2016. január 26-ai csoporttalálkozóján elhangzott beszélgetés. Leiratot készítette: Keresztes-Takács Orsolya: www.mozeskosaregyesulet.hu/mozes/documents/sum_20160126.pdf Hozzáférés dátuma: 2018. 05. 31.

TAJFel, Henry (1992): The Social Psychology of Minorities. London. The Minority Rights Group TAJfel, Henry - Turner, John C. (2004): The Social Identity Theory of Intergroup Behavior. In John Jost - Jim SidAniUs (eds.) Key readings in socialpsychology. Politicalpsychology: Key readings. New York (NY, USA), Psychology Press. 276-293.

YngVesson, Barbara (2010): Belonging in an Adopted World: Race, Identity, and Transnational Adoption. Chicago, University of Chicago Press 